УДК 342.98

DOI https: / / doi.org/10.32837 / yuv.v0i6.2045

\author{
О. Мілієнко, \\ кандидат юридичних наук, \\ здобувач наукового ступеня \\ доктора наук кафедри адміністративного та господарського права \\ Запорізького національного університету
}

\title{
СУЧАСНІ МЕТОДОЛОГІЧНІ ПІДХОДИ ДО ВСТАНОВЛЕННЯ СУТНОСТІ АДМІНІСТРАТИВНОГО АКТА ЯК ІНСТРУМЕНТУ ЗДІЙСНЕННЯ ФУНКЦЙ ПУБЛІЧНОГО УПРАВЛІННЯ
}

Постановка проблеми. Методологічна складова частина являє собою сукупність дослідницьких методів, за допомогою яких наука досягає своєї основоположної мети - здобуття та приросту нового знання про досліджувані явища та процеси. Арсенал наукових методів, що використовуються адміністративним правом, $€$ надзвичайно широким i включає як емпіричні методи - вимірювання, спостереження, порівняння, - так i суто теоретичні. Останні являють собою навіть не чисто методологічні інструменти, а скоріше теоретико-методологічні рами, що задають певне наукове пояснення досліджуваного об’єкта, в нашому випадку - адміністративного акта.

Передусім оговоримо, що адміністративний акт, будучи основною формою діяльності органів публічної влади, являє собою базове, центральне поняття науки адміністративного права; інакше кажучи, з ним пов'язано багато інших адміністративно-правових категорій.

Стан наукової розробки проблеми. Тривала діяльність 3 удосконалення чинного адміністративно-процедурного законодавства своїм результатом має дискусійність розуміння категорії «адміністративний акт». Так, науково-теоретичні розробки присвячені визначенню сутності адміністративного акта, його проце- дурних аспектів $є$ результатом діяльності таких вчених, як В.Б. Авер'янов, О.Ф. Андрійко, А.I. Берлач, Ю.П. Битяк, В.М. Бевзенко В.М. Гаращук, І.П. Голосніченко, В.В. Зуй, T.О. Коломоєць, В.К. Колпаков, Н.Р. Нижник, С.Г. Стеценко, Ю.О. Фрицький, В.О. Шамрай, B.К. Шкарупа та ін. Тривають процеси реформування адміністративно-судочинного та адміністративно-процедурного законодавства, які вимагають визначення методів наукового пізнання, що дасть змогу вирішити потреби практики правозастосування.

Метою статті визначено встановлення сучасних методологічних підходів до встановлення сутності адміністративного акта як інструменту здійснення функцій публічного управління.

Виклад основного матеріалу. Для глибшого розуміння суті адміністративного акта варто додатково використати версію системного підходу, в якій як систему буде розглянуто сукупність правових актів органів виконавчої влади. Метою дослідницького пошуку в такому разі, окрім безпосереднього аналізу системної ролі й місця адміністративного акта, буде розкриття своєрідності цієї системи, виявлення в ній специфічних закономірностей та інтегральних якостей [1, с. 135]. Конструкцію зазначеної системи пропонуємо вибудовувати за пізнавальною 
схемою С.С. Алексєєва - як диференційований набір таких складових компонентів права, як галузь, інститут, норма, елемент норми [2, с. 22].

Таким чином, високий евристичний потенціал системного підходу характеризується можливістю розгляду системи адміністративного права, складником якої є адміністративний акт, на кількох рівнях: як підсистеми соціуму, як складового елементу сучасного права, як окремої системи. Залежно від завдань дослідження, їх уточнення й конкретизації у процесі аналітичної роботи оптику системного підходу можна змінювати, умовно кажучи, «укрупнюючи» окремі елементи системи як предмети дослідження.

У світлі амбівалентної природи й відповідного подвійного розуміння адміністративного акта - як дії та як тексту документа - дозволимо собі припустити, що серед філософських засад дослідження адміністративного акта одне з провідних місць має належати герменевтиці.

$\mathrm{y}$ найзагальнішому аспекті герменевтику у сфері юриспруденціі трактують як науку про розуміння, пояснення значення різних нормативно-правових форм і їх джерел із метою узгодження нормативних документів для вирішення юридичних казусів [3, с. 20]. Г.-Г. Гадамер, засновник цієї філософської течії, вказував на існування певної напруги між відомостями закону як тексту, з одного боку, і тим текстом, який є результатом застосування закону в конкретній ситуаціï тлумачення (приміром, судовий вирок) - $з$ іншого; саме ця напруга, на його думку, є об'єктом юридичної герменевтики. Правильне розуміння тексту нормативного акта під таким кутом зору являє собою подвійну дію; його невід'ємними складниками $€$ проникнення в значення того або іншого нормативного тексту та одночасне його застосування до конкретного випадку [4, с. 20]. Саме розуміння, інтерпретація й застосування, таким чином, виступають ключовими поняттями юридичної герменевтики. Для герменевтичного підходу характерна тотожність між висловом як мовною дією та змістом вислову, його тексту. За словами іншого представника філософської герменевтики, П. Рікера, «способом існування дискурсу є акт, його невідкладність, що має природу події. Вислів $є$ актуальною подією» [5, с. 134]. Іншими словами, тексту в герменевтиці завжди надається характеристика індивідуальності, актуальності; він не може бути зрозумілим раз і назавжди; щоразу його треба трактувати по-новому, залежно від ситуаціі.

Такий підхід, на нашу думку, перегукується з розумінням адміністративного акта в його правозастосувальному аспекті. Будучи рішенням у конкретній індивідуальній справі приватної особи, адміністративний акт вибудовується на підставі певних нормативних приписів, тобто являє собою акт інтерпретації публічним органом законів або інших нормативноправових актів стосовно конкретної ситуації. 3 іншого погляду, адміністративний акт як акт інтерпретації нормативно-правового акта, своєю чергою, сам стає предметом інтерпретації - вже з боку тих, кому він адресований. Тобто адміністративний акт під кутом зору герменевтики являє собою об’єкт подвійного тлумачення.

Таким чином, філософський базис нашої методологічної моделі дослідження адміністративного акта ми пропонуємо у вигляді конструкції 3 трьох логіко-філософських методів пізнання та пояснення реальності: діалектики, філософської герменевтики та системного підходу. Саме ці методологічні течії задають напрями подальшого дослідження, надаючи повноти й поліаспектності нашому науковому аналізу.

Говорячи про загальнонауковий рівень методології пізнання адміністративних явищ, передусім маємо згадати теорію держави $i$ права. У процесі історіографічного ана- 
лізу ми вже згадували про значення концепцій розподілу влади та правової держави для виникнення та розвитку доктрини адміністративного акта в німецькій адміністративно-правовій науці. Саме керуючись розумінням правової держави як управління закону та наявністю судового контролю за діями, які здійснює уряд, юристи дійшли до догматичної розробки понять і принципів публічного права, щоби принципи завдали бажану спрямованість під час здійснення управлінської діяльності, а суди отримали змогу перевіряти адміністративні дії на співвідношення із правовим масштабом (вкотре нагадаємо, що саме тут зародилося поняття адміністративного акта як форми адміністративної діяльності й інструмента судового контролю за законністю цієї діяльності). При цьому новонароджене адміністративне право певною мірою спиралося на інституційні засади приватного права - зрозуміло, з урахуванням особливостей публічно-правової дійсності [6, с. 30].

Неможливо пройти повз icmoріографічний метод дослідження як складника методологічної моделі дослідження адміністративного акта. Метафорично його значення можна висловити, використовуючи цитату відомого французького історика, представника видатної французької історіографічної школи «Анналів» Ф. Броделя: «Будь-яка "сучасність" включає в себе різні рухи, різні ритми: “сьогодні" почалося одночасно вчора, позавчора й “колись”" [7, с. 129]. Іншими словами, вивчення минулого слугує вагомою підставою для розуміння сучасності та прогнозування майбутнього; якщо йдеться про наукові поняття та концепції, як у нашому випадку, історіографічний метод дає змогу вловити соціокультурний контекст становлення певних наукових ідей, дослідити причини та наслідки їх поширення або, навпаки, невикористання, обгрунтувати традиційність або інноваційність як провідну характеристику досліджуваного концепту чи доктрини.

Саме цього ефекту, сподіваємось, нам вдалося досягти в процесі авторського історіографічного аналізу становлення вітчизняної доктрини про адміністративний акт. Визначивши ї генетичні корені в працях німецьких адміністративістів, прослідкувавши розвиток дореволюційної наукової думки стосовно адміністративного акта, окресливши діапазон адміністративно-правових трактувань досліджуваного явища в радянський період, ми дійшли висновку про історично зумовлений характер наявності протилежних теоретичних моделей адміністративного акта в сучасній українській адміністративістиці.

Важливе місце серед гносеологічних засобів адміністративного права посідає теорія управління, яку без усяких сумнівів треба включити до нашого методологічного переліку. Крізь призму теорії управління адміністративний акт розглядається як прийняття відповідним органом (особою) управлінського рішення.

Під цим методологічним кутом зору стає наочною першорядна значущість адміністративного акта в публічному управлінні, адже, за словами дослідників, прийняття управлінського рішення $є$ суттю управління [1, с. 51], а в механізмі публічного управління прийняття рішень у формі адміністративних актів завжди вважалось основним ланцюгом [8, с. 27]. До того ж, приміром, В.П. Усманська доповнює аналіз адміністративного акта як управлінського рішення розглядом процесу вироблення й технології прийняття управлінського рішення, який відображує основні стадії розроблення й видання адміністративних актів. На підставі цього дослідниця доходить висновку, що процес прийняття адміністративного акта є не чим іншим, як процесом вироблення і прийняття управлінського рішення [1, с. 52].

Взагалі у теорії управління процес управління розуміється як постійний 
обмін інформацією між об’єктом управління та органами управління. Удосконалення управління в такому аспекті може бути розкрито як переведення цього інформаційного обміну на вищий ступень організації. Інформація, яка пов'язує об'єкт та суб'єкта управління в єдину систему, слугує підставою для вироблення управлінських рішень та впливів суб'єкта на об'єкт управління. За висновком Ю.О. Тихомирова, сьогоденність характеризується значним ускладненням механізму прийняття й виконання рішень: з одного боку, теорія соціальних систем і теорія рішень, 3 іншого - полісистемність, багаторівневість регулювання. У цьому світлі адміністративний акт перестає бути формалізованим рішенням, яке зобов'язаний ухвалити об'єкт управління; в ньому має відбиватися пізнавальний аспект управління, який набуває особливого значення в умовах використання новітніх інформаційних технологій. Цей пізнавальний аспект полягає у глибокому аналізі та коректному використанні інформації, встановленні сумірності обсягу інформації та змісту рішення, що має запобігти управлінським помилкам. Крім того, реалізація адміністративних актів в умовах інформаційного та постінформаційного суспільства, на думку дослідника, загострює проблеми зміни адміністративних повноважень, статусів службових осіб, сумісної відповідальності, усних діалогових та електронних рішень. Питання відповідальності за прийняття або неприйняття адміністративного рішення своєю чергою має розглядатися крізь призму необхідності реалізації компетенції за допомогою легальних засобів, а для цього потрібні чіткі підстави прийняття рішень, а також не менш чіткі підстави відповідальності публічних службовців [8, с. 27-28].

Взагалі під таким кутом зору світлі функція підготовки та прийняття адміністративного акта як управлінського рішення виступає визначальною, пронизує весь процес управління та всі інші функції управлінського циклу, тому що управлінське рішення діє швидко й реалізується протягом усіх інших стадій управлінського циклу; навіть більше, всі подальші функціï управління підкорюються цілям і задачам, сформульованим у цьому рішенні [9, с. 28]. У зв'язку із цим актуальним стає питання ризиків у процесі прийняття управлінських рішень, тобто підготовці адміністративних актів. I адміністративістам, вважає Ю.О. Тихомиров, потрібно брати до уваги цей аспект; зі свого боку, вчений пропонує такий перелік найбільш типових управлінських ризиків, що супроводжують процес прийняття адміністративного акта: а) недооцінка та неналежне використання аналітичної інформаціі; б) стратегічні та юридичні помилки; в) порушення компетенції; г) недооцінка можливих юридичних колізій; г) відсутність прогнозування соціальних аспектів рішення. Для попередження зазначених ризиків у процесі застосування адміністративних актів у публічно-владній діяльності, на думку науковця, необхідна система «антиризикових» дій, передусім прогностичного характеру [10, с. 13].

Безумовно, у процесі пізнання адміністративного акта як правового інституту неможливо обійтися без використання таких загальнонаукових методів, як методи формальної логіки, які за характером виступають як засоби мислення. Класичний набір цих методів - аналіз і синтез, індукція та дедукція, порівняння, аналогія - $є$ обов'язковим у здійсненні будь-яких пізнавальних операцій для створення простору аналітичного наукового мислення. За їх допомогою відбувається інтерпретація юридичних термінів, конструюються докази та заперечення у процесі міркувань та формулювання висновків, провадиться розгляд та аналіз юридичних фактів тощо. 
Спеціально-юридичний рівень нашої методологічної моделі дослідження правового явища адміністративного акта репрезентований двома методами: формально-юридичним та методом тлумачення. Формально-юридичний (або, як його називають в інших джерелах, догматичний) метод орієнтований, передусім, на дослідження офіційно визнаних встановлених державою норм права. При цьому найважливішою властивістю права визнається його формальна визначеність. Застосування цього методу дає змогу за допомогою логічних операцій виявити юридичну природу досліджуваних явищ, обгрунтувати визначення понять, що пропонуються дослідником, структурувати й систематизувати право [11, с. 26].

Зміст догматичного методу, за словами відомого адміністративіста С.С. Алексєєва, полягає в зовнішній юридичній обробці правового матеріалу (догми права) та включає такі прийоми: 1) опис юридичних норм, юридичної практики тощо; 2) встановлення ознак правових явищ, вироблення понять і їх визначення в коротких формулах; 3) класифікацію правових явищ; 4) встановлення їхної правової природи з точки зору правових конструкцій, загальних положень юридичної науки; 5) ї пояснення під кутом зору юридичних теорій та концепцій [2, с. 358-359].

Взагалі формально-юридичному підходу притаманні такі особливості: уловний характер правових моделей; сумірність формальній логіці; послідовність смислу та змісту; практична перевірка наукових тверджень; прикладний характер; системність та взаємопов'язаність категорій [12, с. 95].

Стосовно предмета нашого дослідження використання догматичного методу буде незамінним у процесі визначення юридичної природи адміністративного акта, наданні дефініції цій категорії, розкритті особливостей адміністративної правозастосувальної юридичної техніки тощо.
Застосування методу тлумачення (який, по суті, являє собою практичний аспект юридичної герменевтики) до дослідження адміністративних актів корелює з думкою P.C. Мельника щодо необхідності розроблення теорії тлумачення адміністративного акта в руслі вітчизняної юридичної доктрини. При цьому Р.C. Мельник вказує на практичну значущість названої теорії: інтерпретація адміністративного акта, на переконання вченого, є обов'язковим елементом і його реалізації, і контролю за його законністю $[13$, с. 84].

Згідно з висновками дослідника, інформація, що міститься в адміністративному акті - слова, цифри, діiі, - являє собою лише форму об'єктивації волі суб'єкта публічної влади, який видав (здійснив) цей акт. Саме ця воля й виступає предметом тлумачення адміністративного акта, яке має розкрити іï сутність. Дещо насторожує, зазначимо відверто, висловлене Р.С. Мельником зауваження: «Якщо суб'єкт публічної адміністрації сформулював в адміністративному акті не ту вимогу, яку хотів сформулювати насправді, потрібно тлумачити адміністративний акт відповідно до його волі та думок, не беручи до уваги при цьому словесний (письмовий) зміст акта» [13, с. 85]. Тут, на наш погляд, слід уважно придивитися до персони, що формулює в адміністративному акті не те, що вважає за потрібне висловити: чи відповідає зазначена особа посадовим вимогам? Тобто не варто забувати, що адміністративний акт під кутом зору суб'єктів публічної адміністрації, передусім, являє собою інструмент їхної повсякденної професійної діяльності, а зміст акта, точніше, його відповідність вимогам законності та умовам конкретної ситуації, виступає показником професійності суб'єкта, який цей акт застосовує.

Підхід до інтерпретації адміністративного акта «відповідно до волі та мислей суб'єкта, що його видав, не беручи до уваги при цьому словесного 
(письмового) змісту акта» видається нам таким, що висуває заздалегідь неможливі для виконання вимоги до суб’єктів-споживачів, що потребують конкретного владного рішення у формі адміністративного акта: «здогадайся, мовляв, сама», що тут має на увазі представник публічної влади. До речі, Р.С. Мельник наводить перелік дій, які треба здійснити для встановлення дійсних «волі та думок» суб'єкта адміністрації: визначення дійсної правової природи рішення суб’єкта публічної адміністрації, встановлення відповідності адміністративного акта духу права і букві закону (конкретно - відповідність принципам підтримання людської честі й гідності, основним правам людини і громадянина, відповідність видачі акта компетенції суб'єкта публічної адміністрації тощо), врахування конкретних обставин видачі адміністративного акта [13, с. 86-93]. I це, на наш погляд, дуже зважений та логічний підхід до інтерпретації адміністративного акта, але, зазначимо, інтерпретації експертної, професійної, яка проводитиметься для перевірки законності конкретного адміністративного акта. Щодо тлумачення акта безпосереднім його споживачем - приватною особою, то такий алгоритм дій видається занадто перевантаженим; навряд чи пересічний громадянин зможе провести таку експертизу, намагаючись зрозуміти, чи суб'єкт, який цей акт видав, мав на увазі саме те, що сформулював, чи щось інше. Взагалі ж підхід Р.С. Мельника є небезспірною, але аргументованою, цікавою та дуже своєчасною спробою застосувати здобутки філософської герменевтики у практичній площині сучасного адміністративного права. Доктрина тлумачення адміністративного акта тільки починає свій шлях в українській адміністративістиці, на якому, сподіваємось, нам доведеться побачити ще багато різних теоретичних пропозицій та дискусій.

Висновок. Таким чином, методологічна модель дослідження адмі- ністративного акта є складною багаторівневою конструкцією. Лише сукупність різноспрямованих засобів та методів пізнання робить можливою продуктивну аналітичну роботу з опису та розуміння досліджуваного адміністративно-правового інституту. Методологічний інструментарій нашого дослідження належить до неокласичної парадигми та включає як суто теоретичні, так і прикладні методики, що, на нашу думку, стане запорукою якнайповнішого висвітлення різних аспектів та особливостей адміністративного акта.

Метою наукової статті визначено встановлення сучасних методологічних підходів до встановлення сутності адміністративного акта як інструменту здійснення функцій публічного управління. У процесі здійсненого дослідження встановлено, що методологічна складова частина є сукупністю дослідницьких методів, за допомогою яких наука досягає своєї основоположної мети - здобуття та формування нового знання про досліджувані явища та процеси. Наголошено, що арсенал наукових методів, що використовуються адміністративним правом, є надзвичайно широким $i$ включае як емпіричні методи - вимірювання, спостереження, порівняння, - так i суто теоретичні. З’ясовано, що адміністративний акт, будучи основною формою діяльності органів публічної влади, є базовим, иентральним поняттям науки адміністративного права, що перебувае в кореляційних зв'язках із багатьма іншими адміністративно-правовими категоріями (адміністративною процедурою, публічно-владними відносинами тощо). На підставі наявності полісемантичних науково-дослідних зв'язків згаданої категорії з іншими адміністративно-правовими інститутами підкреслено складність вибору 
належного методологічного базису, що вимагає комплексного підходу до визначення наукового інструментарію різних теоретичних конструкиій. 3 урахуванням усталеної в адміністративно-правових дослідженнях традищї обтрунтовано доцільність використання трирівневої методологічної моделі наукового пізнання сутності поняття адміністративного акта, що складається з філософського, загальнонаукового та спеціально-юридичного рівнів. Зроблено висновок, що методологічна модель дослідження адміністративного акта є складною багаторівневою конструкиією. Лише сукупність різноспрямованих засобів та методів пізнання робить можливою продуктивну аналітичну роботу з опису та розуміння досліджуваного адміністративно-правового інституту. Методологічний інструментарій нашого дослідження належить до неокласичної парадигми та включає як суто теоретичні, так і прикладні методики, що, на нашу думку, стане запорукою якнайповнішого висвітлення різних аспектів та особливостей адміністративного акта.

Ключові слова: адміністративний акт, діалектичний метод, методологія, поліаспектність, системний метод, філософський метод наукового пізнання.

Milienko O. Modern methodological approaches to establishing the essence of an administrative act as a tool for implementing the functions of public governance

The purpose of the scientific article is to establish modern methodological approaches to establishing the essence of the administrative act as a tool for the implementation of public administration functions. In the course of the research it was established that the methodological component is a set of research methods by which science achieves its fundamental goal - the acquisition and formation of new knowledge about the studied phenomena and processes. It is emphasized that the arsenal of scientific methods used in administrative law is extremely wide and includes both empirical methods measurement, observation, comparison - and purely theoretical. It was found that the administrative act, being the main form of activity of public authorities, is the basic, central concept of the science of administrative law; which is correlated with many other administrative and legal categories (administrative procedure, publicpower relations, etc.). Based on the presence of polysemantic research links of the studied category with other administrative and legal institutions, the difficulty of choosing the appropriate methodological basis is emphasized, which requires a comprehensive approach to the choice of scientific tools of various theoretical constructions. Taking into account the established tradition in administrative and legal research, the expediency of using a three-level methodological model of scientific knowledge of the essence of the concept of administrative act, consisting of philosophical, general and special legal levels. It is concluded that the methodological model of research of the administrative act is a complex multilevel construction. Only a set of diverse tools and methods of cognition makes possible productive analytical work on the description and understanding of the studied administrative and legal institution. The methodological tools of our study belong to the neoclassical paradigm and include both purely theoretical and applied methods, which, in our opinion, will be the key to the fullest coverage of various aspects and features of the administrative act.

Key words: administrative act, dialectical method, methodology, polyaspect, system method, philosophical method of scientific knowledge. 


\section{ЮРИАИЧНИЙ ВІСНИК, 2020/6}

\section{Література}

1. Усманская В.П. Система правових актов органов исполнительной власти: теоретические и прикладные аспекты : дис.... д-ра юрид. наук : 12.00.14. Москва 2014. $411 \mathrm{c}$

2. Алексеев C.C. Собрание сочине ний: в 10-ти тm. T. 2 : Специальные вопросы правоведения. Москва: Cтатут, 2010. 471 c

3. Брижко В.М. Філософія права: герменевтика у сфері інформаційного права. Правова інформатика. 2014. № 1 (41). С. 18-22.

4. Гадамер Г.-Г. Истина и метод: основы философской герменевтики / пер. с нем.; обш. ред. и вступ. ст. Б.Н. Бессонова. Москва: Прогресс, 1988. 704 с.

5. Рикер П. Конфликт интерпретаизии. Очерки о герменевтике / пер. с фр.; обш. ред. и вступ. ст. Б.Н. Бессонова. Москва : Academia-Центр, 1995. 414 с.

6. Старилов Ю.Н. Административное право: в 2-х ч. Ч. 1: Нстория. Наука. Предмет. Нормы. Воронеж : Изд-во Воронеж.г. ун-та, 1998. 392 с

7. Бродель Ф. История и общественные науки. Историческая длительность.
Философия и методология истории / под ред. И.С. Кона. Москва, 1977. С. 115-142.

8. Модернизация административного законодательства (иели, задачи, приниипь и актуальные направления) : монография / А.М. Абакирова, М.А. Абдыраев, Г.А. Василевич /и др.] ; отв. ред. А.Ф. Ноздрачев. Москва : Ин-т законодательства и сравнительного правоведения при Правительстве РФ - ИНФРА-М, 2018. 496 с.

9. Шадрин И.П. Подготовка и принятие управленческого решения. Якутск : Якутский гос. ун-m, 1970. $162 \mathrm{c}$

10. Тихомиров Ю.А. Прогнозы и риски в правовой сфере. Журнал российского права. 2014. T. 2. № 3. С. 5-16.

11. Халилова P.М. Спеииально-юридическая методология исследования реализаиии права человека на зашиту закона. Современное право. 2013. № 6. С. 25-28.

12. Петров А.В., Зырянов А.В. Формально-догматический подход в юридической науке в условиях современности. Вестник ЮУрГУ. Серия «Право». 2019. T. 19. № 1. С. 94-99.

13. Мельник Р.С. Исходнье положення теории толкования административного акта. Ежегодник публичного права. 2016. C. $82-93$ 